\title{
Kadınlarda Pilates-Mat Egzersizlerinin Psikolojik Sağlık Üzerine Etkisi
}

\section{The Psychological Health Effects of Pilates-Mat Exercises on Women}

\author{
Gülten SANIOĞLLU ${ }^{1}$ (D), Zeynep MAÇKALI ${ }^{2}$ iD \\ ${ }^{1}$ Life Circle Psikoterapi ve Yaşam Merkezi Ĕ̈itim ve Danışmanlık, İstanbul, Türkiye. \\ ${ }^{2}$ İstanbul Bilgi Üniversitesi, Sosyal ve Beşerî Bilimler Fakültesi, İstanbul, Türkiye.
}

\section{AÇIK ERIŞSiM}

ÖZ: Bu çalışmada kadınlarda pilates-mat egzersizlerinin psikolojik sağlık üzerine nasıl bir etkisi olduğu araştırılmıştır. $\mathrm{Bu}$ amaçla pilates-mat egzersizlerinin depresyon, anksiyete ve yaşam doyumu üzerinde nasıl bir etkisi olduğu incelenmiştir. Araştırmaya deney $(n=15)$ ve kontrol $(n=15)$ grubu olmak üzere toplam 30 kadın katılmıştır. Araştırmada deney grubunda bulunan kadınlara 6 hafta boyunca haftada 3 gün ve günde 1 saat olmak üzere toplam 18 seans pilates egzersiz programı uygulanmıştır. Bu süreçte kontrol grubunda yer alan kadınlar herhangi bir bedensel etkinliğe katılmamıştır. Araştırmanın veri toplama sürecinde "Beck Anksiyete Ölçeği”, "Beck Depresyon Envanteri” ve "Yaşam Doyumu Ölçeğii" kullanılmıştır. Elde edilen veriler bağımlı ve bağımsız örneklem t-testleriyle değerlendirilmiştir. Bağımlı gruplar t-testiyle yapılan analizlerde etki büyüklüğü açısından fark görülmüştür (anksiyete için $t=7.31$, depresyon için $t=8.52$, yaşam doyumu için $\mathrm{t}=-4.15, \mathrm{p}<.05$ ), bağımsız gruplar $\mathrm{t}$-testleriyle yapılan kıyaslamalarda sadece yaşam doyumu değişkeni açısından anlamlı bir etki olduğu görülmüştür (anksiyete için $\mathrm{t}=-.47$, depresyon için $\mathrm{t}=-1.47 \mathrm{p}>.05$; yaşam doyumu $\mathrm{t}=4.93, \mathrm{p}<.01$ ). Sonuç olarak, 18-50 yaş grubunda bulunan kadınlara uygulanan 6 haftalık pilates egzersiz programının depresyon ve anksiyete düzeyinin azalmasına, bunun yanında yaşam doyum düzeyinin yükselmesine katkı sağlayabileceği, bu bağlamda stresle baş etmede destekleyici bir fiziksel egzersiz aktivitesi olarak kullanılabileceği söylenebilir.

Fatih $A \breve{G} D U M A N$

Anahtar Kelimeler: egzersiz, pilates, depresyon, kaygı, yaşam doyumu.

Atatürk Üniversitesi, Spor Bilimleri Fakültesi, Erzurum, Türkiye.

ABSTRACT: The aim of this study is to examine the effects of pilates - mat exercises on psychological health of women. Thus, the effect of pilates-mat exercises on depression, anxiety and life satisfaction was investigated. 15 women were recruited as experimental $(n=15)$ group participants and 15 women as control group participants. Totally 18 sessions of pilates exercise programme which lasted an hour / three days a week during six weeks period was applied to the experimental group. Meanwhile the control participants did not join any physical activity. 'Beck Anxiety Scale', 'Beck Depression Inventory' and 'Scale of Life Satisfaction' were used for the data collection. The paired samples and the independent samples t-tests were used for data analysis. Although dependent t-test analyses revealed significant differences in terms of anxiety $\mathrm{t}=7.31$, for depression $\mathrm{t}=8.52$ and for life satisfaction $\mathrm{t}=-4.15(\mathrm{p}<.05)$, the independent groups $\mathrm{t}$-tests showed that a significant effect was found only in terms of life satisfaction $(\mathrm{t}=4.93, \mathrm{p}<.01)$. In conclusion, it can be said that 6-week pilates exercise program applied to women in the 18-50 age group can contribute to the reduction of depression and anxiety levels, as well as to increase the level of life satisfaction, and also it can be used as a supportive physical exercise activity in coping with stress.

Geliş: 28.12.2020

Kabul: 27.05.2021

Yayınlanma: 30.06 .2021

Keywords: exercise, pilates, depression, anxiety, life satisfaction.

Künye:

Sanioğlu G. \& Maçkalı, Z. (2021). Kadınlarda pilates-mat egzersizlerinin psikolojik sağlık üzerine etkisi. IntJourExerPsyc, 3(1):37-50. https://doi.org/10.51538/intjourexerpsyc. 8483 $\underline{04}$ 


\section{GİRIŞ}

Günümüzde teknolojinin gelişmesiyle birlikte fiziksel hareketsizlik artmıştır. İş hayatında rekabetin artmasıyla birlikte daha fazla strese maruz kalınmaktadır. Çağımızın en önemli sağlık problemlerinden biri olan stres, canlıların vücut fonksiyonlarını bozup, yaşamkaliteleriniolumsuz yönde etkilemektedir (Gencer ve ark., 2015). Modern yaşamla birlikte rekabet ve yarışmacılık, iş hayatında ve sosyal hayatta stresi artıran unsurlardır. Bireyler stresle baş edebilmek için bedensel ve ruhsal sağlıklarını korumak için farklı uygulamalara başvurma ihtiyacı duymaktadır (Güçlü, 2001).

Fiziksel egzersiz aktivitesi, bedensel hareketliliğini artırarak stresin azaltılmasına yardımcı olur. Fiziksel egzersiz aktiviteleri, düzenli olarak yapıldığında zaman ve yere bağımlı olarak egzersiz yapma alışkanlığı edinilmesini amaçlar. Fiziksel egzersizler, planlı olarak uygulanırken germe, gevşeme, esnetme, güçlendirme gibi yöntemler uygulanır ( $\operatorname{Ardlç,~}$ 2014). Fiziksel egzersizlerin bedenle birlikte zihni de rahatlattığı bilimsel araştırmalarda gösterilmiştir ve egzersiz psikolojisi bilim olarak sağlıklı bir yaşam için fiziksel egzersizin gerekli olduğunu ortaya koymaktadır. Egzersiz psikolojisinin temel odak noktası, akut ve kronik egzersizin, psikolojik, davranışsal, sosyal ve bilişsel sebep ve sonuçlarının neler olduğudur (Buckworth \& Dishman, 2002; akt. Yeltepe, 2012).

Fiziksel egzersiz yapmak, bedensel ve ruhsal sağlığı korur. Pilates-mat egzersizlerinin zihne ve bedene hitap eden bir fiziksel ve zihinsel egzersiz türü olarak bedensel sağlığı (Avşar, 2019) ve ruhsal sağlı̆̆ı (Özdemir \& Uysal, 2018) koruduğu ve iyileştirdiği yapılan çalışmalarda gösterilmiştir. Pilates-mat egzersizlerinin psikolojik sorunları azalttığı da saptanmıştır (Vancini ve ark., 2017). Pilates egzersizlerinin kas gücünü artırarak fiziksel dayanıklılığı dakoruduğu ortaya konmuştur. Araştırmacılar aynı zamanda pilates-mat egzersizlerinin zihinsel yapı üzerinde etkilerini de incelemişlerdir. $\mathrm{Bu}$ araştırmalar, genellikle pilates-mat egzersizlerinin bedensel ve bilişsel etkileri üzerine yapılmıştır (Damdelen, 2016).

Depresyon, toplumlarda sıkça görülen bir ruhsal rahatsızlıktır. Depresyonun tedavisi yapılmadığı takdirde bedensel sorunlarla birlikte intihar ve erken ölüme de neden olabilecek sonuçları vardır (Çelik \& Hocaoğlu, 2016). Depresyon, sonuçları itibariyle ekonomik ve sosyal yönden bireyleri ve toplumları etkilemektedir. İş gücü kaybı ve tedavi masrafları oldukça yüksektir (Başoğul \& Buldukoğlu, 2015; Karatayll, 2007). Son yıllarda yapılan araştırmalarda depresyonun neden ve hatta sonuçlarından birinin de fiziksel aktivite yetersizliği olduğu sonucuna varılmıştır (Roshanaei-Moghaddam ve ark., 2009).

Pilates egzersizlerinin depresyon düzeyleri üzerinde olumlu etkisi olduğu araştırmalarla ortaya konmuştur. Mokhtari ve ark. (2013) tarafından pilates egzersizine katılımın yaşlı bireylerin depresyon düzeylerine nasıl bir etkisi olduğu konusunda yapılan ve 30 yaşlı bireyin katıldığı 12 hafta olarak planlanan araştırmada, 12 hafta sonunda düzenli olarak pilates egzersizine katılan katılımcıların depresyon düzeylerinde anlamlı bir düşüş olduğu rapor edilmiştir.

Hassan ve Amin (2011) tarafından yapılan bir diğer araştırmada pilates egzersizlerinin fiziksel ve ruhsal yapı üzerine etkisinin incelenmiş, 30-35 yaşları arasında bulunan 10 kadın araştırmaya dahil edilmiş, araştırma, 12 hafta sürmüştür. Sonucunda 12 hafta boyunca düzenli olarak pilates egzersizine katılımın psikolojik sağlık parametrelerinden olan depresyon düzeylerinde anlamlı bir azalma sağladığı rapor edilmiştir. 
Türk Dil Kurumu (TDK) sözlüğü kaygıyı"endişe ve üzüntü duyulan durum" şeklinde açıklamaktadır. Kayg1, strese karşı verilen normal bir tepkidir. Bununla birlikte normal yaşamı olumsuz şekilde etkileyecek kadar şiddetli ve devamlı olduğunda patolojik bir hal alır. Günümüzde kaygıyı kontrol edebilmek için psikolojik rahatlama teknikleri, nefes egzersizleri ve fiziksel aktivite de tedaviye dahil edilmeye başlanmıştır (Hale, 1998; akt. Yeltepe, 2012).

Pilates egzersizlerinin kaygı düzeyleri üzerinde olumlu etkisi olduğu farklı araştırmalarda ortaya konmuştur. Akbaş ve Ünver (2018) tarafından 18-25 yaş aralığında genç yetişkin kadınlar üzerinde yapılan bir araştırmada pilates egzersizlerine katılımın psikolojik ve bedensel etkileri incelenmiştir. Araştırmaya 51 genç yetişkin kadın katılmıştır. Katılımcılardan pilates-mat egzersizi yaptırılan 25 kişi deney grubunu,herhangi bir fiziksel egzersiz yaptırılmayan 26 kişi ise kontrol grubunu oluşturmuştur. 6 hafta süren çalışma sonunda pilates egzersizlerine katılan deney grubunun psikolojik sağlık parametrelerinden olan kaygı ve depresyon düzeylerinde kontrol grubuna göre anlamlı düzeyde düşüş olduğu rapor edilmiştir.

Fleming ve Herring (2018) tarafından yapılan bir meta-analiz çalışmasında 2017 yılında pilatesin psikolojik sağlık üzerine etkisi konusunda yapılan bir yıllık araştırmaların sonuçlarını incelemişler ve pilates egzersizlerinin depresyon ile kaygıyı azalttığı ve dolayısıyla psikolojik sağlık üzerinde olumlu bir etkisi olduğunu rapor etmişlerdir.

Yaşam doyumu, pozitif psikoloji biliminin son yıllarda ilgilendiği bir kavramdır.Yaşam doyumu, pozitif duyguları içeren yaşam kalitesi, psikolojik sağlık ve sağlamlık gibi kavramları içerir (Kaba ve diğ., 2018). İnsanların tüm yaşamından haz almasını ifade eder. Bireyler,fiziksel ve ruhsal olarak iyi hissettiklerinde ve yaşamdaki beklentileri karşılandığında yaşamaktan keyif alırlar. Her birey yaşamda farklı beklentilere sahiptir. Yaşam doyumu, bu açıdan bakıldığında, bireylerin beklentilerinin karşılanması demektir (Kalfa, 2017).

Pilates egzersizlerinin yaşam doyumu üzerine olumlu etkisi olduğu birçok araştırmada ortaya konmuştur. Örneğin, Dağ ve ark. (2019) tarafindan spor kulüplerinde eğitmen olarak çalışan kadın ve erkek spor eğitmenlerinin egzersize katılımının yaşam doyumları üzerine etkisi incelenmiştir. Araştırmaya 150 spor eğitmeni (104 E, $46 \mathrm{~K}$ ) katılmıştır. Araştırma sonunda pilates egzersizlerine katılan katılımcıların yaşam doyumu düzeylerindeki artışın diğer egzersiz türlerine katılan katılımcıların yaşam doyumu düzeylerine göre daha yüksek olduğu ve yaşam doyum düzeylerindeki artışın cinsiyete göre farkl1lık göstermediği rapor edilmiştir.

Cruz-Ferreira ve ark. (2011) tarafından yapılan, 6 ay süren ve 62 yetişkin kadın katılımcının deney ve kontrol grubu olmak üzere iki gruba ayrıldığı bir diğer araştırmada pilates-mat egzersizlerinin yaşam doyumunu artırdığı sonucuna varılmıştır.

Öztürk (2019) tarafından pilates egzersizine katılımın psikolojik sağlık üzerine etkisi nitel bir araştırmayla incelenmiştir. Araştırmaya uzun süre pilates egzersizleri yapan 32 kadın katılmıştır. Yarı yapılandırılmış yöntemle yapılan nitel araştırma sonucunda uzun süre pilates egzersizlerine katılımın psikolojik sağlık üzerinde olumlu etkisi olduğu sonucuna varılmıştır.

Fiziksel egzersiz aktiviteleri, hareketli bir yaşama sahip olmayı sağlarken, fiziksel egzersiz yapmanın önemini de ortaya çıkarır (Gönülateş ve ark., 2010). Bu tür aktiviteler, fiziksel sağlıkla birlikte psikolojik sağlı̆̆ da korumakta ve iyileştirmektedir. Her yaş grubundan bireylerde farklı biçimlerde olumlu fiziksel ve psikolojik sonuçlar ortaya 
konmaktadır. Fiziksel egzersiz aktivitelerini düzenli olarak yapmanın, fiziksel dayanıklılığı artırarak hareket yapma becerisini ve kondüsyonunuartırdığı, bununla birlikte yaşam süresini uzattığı bildirilmiştir (Özdemir \& Irez, 2010). Fiziksel açıdan aktif bir yaşamın depresyon ve kaygı gibi olumsuz duyguların daha azyaşanmasına yardımcı olurken, yaşam doyumu gibi olumlu duyguların artmasına etki edebileceği söylenebilir. Bu bağlamda, mevcut araştırmada pilates-mat egzersizlerinin kadınlarda depresyon ve anksiyeteyi azaltırken, yaşam doyumunu artıran bir fiziksel egzersiz aktivitesi olarak kullanılıp kullanılamayacağını incelemek amaçlanmıştır.

\section{YÖNTEM}

\subsection{Araştırmanın Modeli}

Araştırmada deney ve kontrol grupları olmak üzere iki bağımsız grup karşılaştırması ve aynı zamanda deney ve kontrol gruplarının ön test puan ortalamalarıyla son test puan ortalamalarının karşılaştırıldığı deneysel model kullanılmıştır. Bu model, yapılan deneyin bağımlı değişken üzerindeki etkisinin kontrol edildiği, neden-sonuç bağlamında yorumlanmasını sağlayan bir modeldir (Büyüköztürk, 2013; akt. Bayram \& Kllıç, 2017).

\section{2. Örneklem}

Araştırmanın örneklemini 18-50 yaş aralığında, İstanbul ilinde ikamet eden, daha öncepilates egzersizi yapmamış, anti-depresan ve herhangi bir ilaç kullanmayan, alkol veya uyuşturucu bağımlısı olmadığını beyaneden 30 kadın oluşturmaktadır. Araştırmadan hariç tutulma kriterleri ise şu şekildedir: Daha önce pilates yapmış olmak, antidepresan veya herhangi bir ilaç kullanmak, egzersiz yapmasına engel olabilecek fiziksel bir rahatsızlığa sahip olmak, hamile olmak veya emzirmek, alkol veya uyuşturucu kullandığını beyan etmek, daha önce depresyon veyaanksiyete tanısı almakve klinik tedavi görmek.

\subsection{Veri Toplama Araçları}

\subsubsection{Kişisel bilgi formu}

Katılımcıların yaş, eğitim, meslek gibi demografik bilgilerinin yanında sigara, alkol, uyuşturucu, antidepresan veya herhangi bir ilaç kullanımıyla ilgili bilgilere ve daha önce pilates yapıp yapmadığı ve egzersiz yapmasına engel bir fiziksel rahatsızlık olmadığına dair bilgiler alınmıştır.

\subsubsection{Beck Anksiyete Ölçeği}

Beck ve ark. (1988) tarafından geliştirilmiş, Türkçe'ye uyarlaması ve geçerlik, güvenirlik çalışması Ulusoy ve ark. (1998) tarafından yapılan ölçekte bireylerin kaygı düzeyleri, 0-3 arasında puanlanan 21 sorudan oluşmaktadır. Son bir haftada bireyin yaşadığı kaygı düzeyi, 0-63 puanları arasında hafif,orta,ileri,ağır kaygı düzeyleri olarak ölçülmektedir. Türkçe uyarlama çalışmasında Cronbach Alfa iç tutarlılık katsayıs1 .93, test tekrar test güvenirliği ise .57 , madde toplam korelasyon katsayılarının .45 - .72 arasında değerlere sahip olduğu belirtilmiştir (Kuran, 2018).

\subsubsection{Beck Depresyon Envanteri}

Beck ve ark. (1961) tarafından geliştirilmiş olan ve Türkçe uyarlaması, geçerlilik ve güvenilirlik çalışması Hisli (1989) tarafından yapılmıştır. Katılımcıların son iki haftadaki kendilerini nasıl hissettikleri üzerinden 21 soruyu 0-3 
arasında puanlayarak cevaplandırması istenmektedir. 0-63 puan aralığında alınan puanlar hafif,orta,yüksek düzey olarak derecelendirilmektedir. Ölçeğin Türkçeye uyarlamasında güvenirlik katsayısının .74 olduğu, korelasyon ilişkisi r $=.73$ olarak belirtilmiştir (Kllınç \& Torun, 2011).

\subsubsection{Yaşam Doyumu Ölçeği}

Diener ve ark. (1985) tarafından geliştirilmiş, Türkçe'ye uyarlaması, geçerlilik ve güvenilirlik çalışması Köker (1991) tarafından yapılmıştır. Ölçekte bireylerin hayatlarının genelini nasıl değerlendirdiklerini ölçmeyi hedefleyen, 7'li likert ile değerlendirilen 5 olumlu madde vardır. Türkçe geçerlik ve güvenirlik çalışmasında güvenirlik katsayısının 0.85 olduğu ifade edilmiştir (Çivitçi, 2012).

\section{4. İşlem}

Araştırmaya İstanbul Arel Üniversitesi Etik Kurulu'na başvurularak etik izin alınarak başlanmıştır (23.10.2019 Tarihli 09 No'lu karar). 1 Kasım-15 Aralık 2019 tarihleri arasında 6 hafta süren araştırma, İstanbul ilinde Küçükçekmece ilçesinde araştırmacıya ait Life Circle Pilates stüdyosunda yapılmıştır. Araştırmacı, pilates eğitmenlik sertifikasına sahiptir. Katılımcılara sosyal medya üzerinden duyurular yapılarak ulaşılmıştır. Araştırmanın amacı ve aşamaları, verilerin güvenliği ve egzersizlerin nasıl yapılacağıyla ilgili aşamalar açıklanarak kişisel bilgi formu ve gönüllü katılım onam formu araştırmaya başlamadan önce imzalatılmıştır. Deney grubu, pilates-mat egzersizleri uygulanan grup; kontrol grubu ise herhangi bir fiziksel egzersiz uygulamasına katılmayan gruptur. Örneklem seçimi, ulaşılabilirlik örneklemine göre yapılmıştır. Araştırmaya gönüllü olarak katılan 30 kadın katılımcı seçkisiz olarak atanarak iki grup [Deney $(\mathrm{n}=15)$ ve kontrol $(\mathrm{n}=15)]$ oluşturulmuştur.

6 hafta süren araştırmada katılımcılara haftada 3 gün birer seans olmak üzere toplam 18 seans pilates-mat egzersizleri araştırmacı tarafından yaptırılmıştır. Egzersizler 5'er kişilik gruplar halinde, 60 dakikalık seanslar olarak (15 dakika esneme, 30 dakika direnç ve son 15 dakikası gevşeme) planlanmıştır. Pilates-mat egzersizlerinde pilates topu ve pilates çemberi kullanılmıştır. Egzersizler, müzik eşliğinde yapılımıştır. Seanslara katılamayan katılımcılar, aranarak uygun oldukları gün ve saatte birebir seans yapılarak 18 seansın tamamlanması sağlanmıştır. 18 seans eksiksiz olarak 6 haftada tamamlanmıştır.

Araştırmanın başında gönüllü katılımcı onam formu ve kişisel bilgi formu imzalatılmış, ardından ölçekler doldurularak egzersizlere başlamadan önce ön test puanları alınmıştır. Daha sonra deney grubundaki katılımcılarla 18 oturumluk programa başlanmıştır. Ön test puanları alınan kontrol grubu katılımcıları ise 6 hafta boyunca herhangi bir fiziksel egzersiz ve pilates egzersizine katılmamıştır. 6 hafta 18 seans pilates-mat egzersizlerini tamamlayan deney grubundaki katılımcılara son ölçümlerini almak üzere ölçekler yeniden uygulanmış, bununla birlikte 6 hafta sonunda herhangi bir egzersiz ve pilates egzersizi yaptırılmayan kontrol grubundaki katılımcılara da ölçekler uygulanarak her iki grubun da son test puanları alınmıştır.

\subsection{Verilerin Analizi}

Verilerin analizinde SPSS 22.0 programı kullanılmıştır. Analizlerde $\mathrm{p}<.05$ istatistiksel olarak anlamlı kabul edilmiştir. Analizlerde çarpıklık ve basıklık değerleri -2 ve +2 arasında olduğundan, normal dağılımın olduğu kabul edilerek parametrik testler yapılmasına karar verilmiştir (Sposito ve ark., 1983). Deney ve kontrol gruplarının ön test ve son test puanlarının karşılaştırılmasında bağımlı örneklem t-testi kullanılmıştır. Deney ve kontrol gruplarının son test 
puanlarının karşılaştııılmasında ise bağımsız örneklemler t testi kullanılmıştır. Etki büyüklüğünün hesaplanması için Cohen's d formülü ( $\mathrm{d}=$ ortalamalar arası fark / standart sapma) kullanılmıştır. Etki büyüklügünün yorumlanmasında $\mathrm{d}$ $\geq 1$ çok büyük etki, 0.8 büyük etki, 0.5 orta etki, 0.2 küçük etki olarak dikkate alınmıştır (Kılıç, 2014).

\section{BULGULAR}

Tablo 1. Deney ve kontrol grubundaki katılımcıların yaş ortalamaları

\begin{tabular}{lccccc}
\hline Grup & $\mathbf{n}$ & $\overline{\mathbf{x}}$ & ss & Min. & Max. \\
\hline Deney & 15 & 36.60 & 8.19 & 25 & 49 \\
Kontrol & 15 & 37.67 & 11.94 & 20 & 50 \\
\hline
\end{tabular}

Deney grubu katılımcılarının yaşları 25-49 arasında değişirken, yaş ortalamaları 36.60’tır (ss: 8.19). Kontrol grubu katılımcılarının yaşları 20-50 arasında değişirken, yaş ortalamaları 37.67' dir (ss: 11.94).

Tablo 2. Katılımcıların eğitim düzeylerine ilişkin dağılımı

\begin{tabular}{lllclc}
\hline Değişken & & \multicolumn{2}{c}{ Deney } & \multicolumn{2}{c}{ Kontrol } \\
\hline \multirow{2}{*}{ Eğitim Durumu } & ṅlkokul & - & \% & n & \% \\
& Ortaokul & - & - & 1 & 6.7 \\
& Lise & 2 & 13.3 & 3 & 6.7 \\
& Ön Lisans & 3 & 20.0 & 2 & 13.3 \\
& Lisans & 8 & 53.3 & 7 & 46.7 \\
& Yüksek Lisans & 1 & 6.7 & 1 & 6.7 \\
& Doktora & 1 & 6.7 & - & - \\
\hline
\end{tabular}

Araştırmaya katılan deney grubunda 2 kişi lise, 3 kişi ön lisans, 8 kişi lisans, 1 kişi yüksek lisans, 1 kişi ise doktora mezunudur. Kontrol grubundan 1 kişi ilkokul, 1 kişi ortaokul, 3 kişi lise, 2 kişi ön lisans, 7 kişi lisans, 1 kişi ise yüksek lisans mezunudur.

\section{Bağımlı Örneklem T-Testi Sonuçları}

Deney ve Kontrol Grubunun Ön Test- Son Test Sonuçlarının Karşılaştırılması

Tablo 3. Deney ve kontrol gruplarının anksiyete düzeylerindeki değişimin ön test ve son test arasındaki karşılaştırılması

\begin{tabular}{ccccccccc}
\hline Grup & Değişken & Testler & $\mathbf{F}$ & $\overline{\mathbf{x}}$ & $\mathbf{s s}$ & $\mathbf{t}$ & $\mathbf{p}$ & $\mathbf{d}$ \\
\hline \multirow{2}{*}{ Deney } & \multirow{2}{*}{ BAÖ } & Ön Test & 15 & 18.47 & 9.20 & \multirow{2}{*}{7.313} & .000 & 1.89 \\
& & Son Test & 15 & 15.40 & 8.30 & & & \\
\hline \multirow{2}{*}{ Kontrol } & \multirow{2}{*}{ BAÖ } & Ön Test & 15 & 16.73 & 7.85 & \multirow{2}{*}{1.000} & .334 & - \\
& & Son Test & 15 & 16.80 & 7.86 & & & \\
\hline
\end{tabular}

Deney grubu katılımcilarının ön test anksiyete ortalaması ( $\overline{\mathrm{x}}: 18.47)$ ile son test anksiyete ortalamasının ( $\overline{\mathrm{x}}: 15.40)$ karşılaştırılmasında bağımlı gruplar t-testi kullanılmış ve iki ölçüm arasında anlamlı farklılık olduğu tespit edilmiştir 
$(\mathrm{t}=7.313 ; \mathrm{p}<.05)$. Deney grubunda ön test anksiyete ortalaması $(\overline{\mathrm{x}}: 18.47)$, son test anksiyete ortalamasina $(\overline{\mathrm{x}}: 15.40)$ göre anlamlı ölçüde yüksektir. Bu durum, deney grubunun pilates-mat egzersizleriyle anksiyete düzeylerinde anlamlı bir düşüş olduğunu göstermektedir.

Yapılan etki büyüklüğü testi analizi sonucunda ise etki büyüklüğünün 1.89 olduğu belirlenmiştir. Bu durum deney grubuna verilen pilates eğitiminin anksiyete düzeyinin azaltılmasında anlamlı bir etkiye sahip olduğunu göstermektedir.

Kontrol grubu katılımcılarının ön test anksiyete ortalaması ( $\overline{\mathrm{x}}: 16.73)$ ile son test anksiyete ortalamasının ( $\overline{\mathrm{x}}$ : 16.80) arasında anlamlı farklılık tespit edilmemiştir ( $\mathrm{t}=-1.000 ; \mathrm{p}>.05)$.

Tablo 4. Deney ve kontrol gruplarının depresyon düzeylerindeki değişimin ön test ve son test puanları aracılığıyla karşılaştırılması

\begin{tabular}{|c|c|c|c|c|c|c|c|c|}
\hline Grup & Değişken & Testler & $\mathbf{F}$ & $\overline{\mathbf{x}}$ & ss & $\mathbf{t}$ & $\mathbf{p}$ & d \\
\hline \multirow{2}{*}{ Deney } & \multirow{2}{*}{ BDÖ } & Ön Test & 15 & 15.73 & 9.20 & \multirow{2}{*}{8.527} & \multirow{2}{*}{.000} & \multirow{2}{*}{2.20} \\
\hline & & Son Test & 15 & 12.87 & 8.49 & & & \\
\hline \multirow{2}{*}{ Kontrol } & \multirow{2}{*}{ BDÖ } & Ön Test & 15 & 17.00 & 7.01 & \multirow{2}{*}{-1.000} & \multirow{2}{*}{.334} & \multirow{2}{*}{ - } \\
\hline & & Son Test & 15 & 17.07 & 7.09 & & & \\
\hline
\end{tabular}

BDÖ: Beck Depresyon Ölçeği

Deney grubu kat1lımc1larının ön test depresyon ortalaması $(\overline{\mathrm{x}}: 15.73)$ ile son test depresyon ortalamas1 ( $\mathrm{x}: 12.87)$ arasında anlamlı farklılık olduğu gösterdiği bulunmuştur $(\mathrm{t}=8.527 ; \mathrm{p}<.05)$. Deney grubunda ön test depresyon ortalaması $(\overline{\mathrm{x}}: 15.73)$, son test depresyon ortalamasına ( $\mathrm{x}: 12.87)$ göre anlamlı ölçüde yüksektir.

Yapılan etki büyüklüğü testi sonucunda ise etki büyüklüğünün 2,20 olduğu belirlenmişstir. Bu durum deney grubuna verilen pilates eğitiminin depresyon düzeyinin azaltılmasında anlamlı bir etkiye sahip olduğunu göstermektedir $(d \geq 1)$.

Kontrol grubu katılımc1larının ön test depresyon ortalaması ( $\mathrm{x}: 17.00)$ ile son test depresyon ortalamasının $(\overline{\mathrm{x}}: 17.07)$ anlamlı farklılık göstermediği tespit edilmiştir ( $\mathrm{t}=-1.000 ; \mathrm{p}>.05)$.

Tablo 5. Deney ve kontrol gruplarının yaşam doyum düzeylerindeki değişimin ön test ve son test puanları aracılığıyla karşılaştırılması

\begin{tabular}{|c|c|c|c|c|c|c|c|c|}
\hline Grup & Değişken & Testler & $\mathbf{F}$ & $\overline{\mathbf{x}}$ & ss & $\mathbf{t}$ & $\mathbf{p}$ & d \\
\hline \multirow{2}{*}{ Deney } & \multirow{2}{*}{ YDÖ } & Ön Test & 15 & 24.20 & 5.17 & \multirow{2}{*}{-4.150} & \multirow{2}{*}{.001} & \multirow{2}{*}{1.07} \\
\hline & & Son Test & 15 & 27.33 & 3.27 & & & \\
\hline \multirow{2}{*}{ Kontrol } & \multirow{2}{*}{ YDÖ } & Ön Test & 15 & 17.73 & 7.27 & \multirow{2}{*}{.845} & \multirow{2}{*}{.413} & \multirow{2}{*}{ - } \\
\hline & & Son Test & 15 & 17.47 & 7.03 & & & \\
\hline
\end{tabular}

YDÖ: Yaşam Doyum Ölçeği

Deney grubu katılımcılarının ön test yaşam doyum ortalamasının ( $\bar{x}: 24.20)$ ile son test yaşam doyum ortalamasına $(\overline{\mathrm{x}}: 27.33)$ kıyasla, anlamlı farklılık gösterdiği hesaplanmıştır $(\mathrm{t}=-4.150 ; \mathrm{p}<.05)$. Deney grubunda son test yaşam doyum

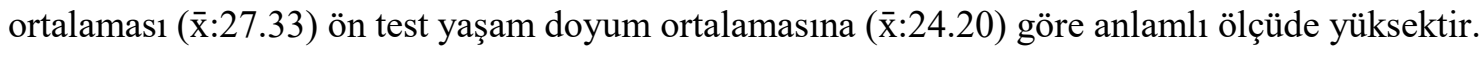


Yapılan etki büyüklüğü testi sonucunda ise etki büyüklüğünün 1.07 olduğu belirlenmiştir. Bu durum deney grubuna verilen pilates eğitiminin yaşam doyumun artmasında anlamlı bir etkiye sahip olduğunu göstermektedir $(\mathrm{d} \geq 1)$.

Kontrol grubu katılımcılarının ön test yaşam doyum ortalaması( $\overline{\mathrm{x}}$ : 17.70) ile son test yaşam doyum ortalamasının ( $\mathrm{x}: 17.47) a n l a m l ı$ farklılık göstermediği tespit edilmiştir ( $\mathrm{t}=.845 ; \mathrm{p}>.05)$.

\section{Bağımsız Örneklem T-Testi Sonuçları}

Deney ve Kontrol Gruplarının Karşılaştırılması

Tablo 6. Deney ve kontrol grubunun ön test - son test anksiyete düzeylerinin karşılaştırılması

\begin{tabular}{llllcccc}
\hline Değişken & Grup & Testler & F & $\overline{\mathbf{x}}$ & ss & $\mathbf{t}$ & $\mathbf{p}$ \\
\hline \multirow{2}{*}{ BAÖ } & Deney & Ön Test & 15 & 18.47 & 9.20 & .555 & .583 \\
& Kontrol & Ön Test & 15 & 16.73 & 7.85 & & \\
\hline \multirow{2}{*}{ BAÖ } & Deney & Son Test & 15 & 15.40 & 8.30 & \multirow{2}{*}{.474} & .639 \\
& Kontrol & Son Test & 15 & 16.80 & 7.86 & & \\
\hline
\end{tabular}

Deney ve kontrol grubunun anksiyete düzeylerinin ön test-son test puanları arasındaki karşılaştırmaya göre, anksiyete düzeylerinde istatistiksel olarak anlamlı bir farklılı̆̆ın olmadığı belirlenmiştir $(\mathrm{t}=-.474, \mathrm{p}>.05)$.

Tablo 7. Deney ve kontrol grubunun ön test-son test puanlarına depresyon düzeylerinin karşılaştırılması

\begin{tabular}{cllccccc}
\hline Değişken & Grup & Testler & F & $\overline{\mathbf{x}}$ & ss & t & p \\
\hline \multirow{2}{*}{ BDÖ } & Deney & Ön Test & 15 & 15.73 & 9.20 & & \\
& Kontrol & Ön Test & 15 & 17.00 & 7.01 & -.424 & .675 \\
\hline \multirow{2}{*}{ BDÖ } & Deney & Son Test & 15 & 12.87 & 8.49 & & \\
& Kontrol & Son Test & 15 & 17.07 & 7.09 & -1.471 & .153 \\
\hline
\end{tabular}

Deney ve kontrol gruplarının depresyon düzeylerinin ön test-son test puanlarının karşılaştırmalarına göre, depresyon düzeylerinde anlamlı farklılı̆̆ın olmadığı belirlenmiştir ( $(=-1.47, \mathrm{p}>.05)$.

Tablo 8. Deney ve kontrol grubunun yaşam doyumu düzeylerinin karşılaştırılması

\begin{tabular}{clllcccc}
\hline Değişken & Grup & Testler & F & $\overline{\mathbf{x}}$ & ss & $\mathbf{t}$ & $\mathbf{p}$ \\
\hline \multirow{2}{*}{ YDÖ } & Deney & Ön Test & 15 & 24.20 & 5.17 & & \\
& Kontrol & Ön Test & 15 & 17.73 & 7.27 & 2.806 & .010 \\
\hline \multirow{2}{*}{ YDÖ } & Deney & Son Test & 15 & 27.33 & 3.27 & & \\
& Kontrol & Son Test & 15 & 17.47 & 7.03 & & .000 \\
\hline
\end{tabular}

YDÖ: Yaşam Doyum Ölçeği

Deney ve kontrol grubunun yaşam doyum düzeylerinin ön test-son test karşılaştırmalarına göre, deney grubunun ön test yaşam doyumu ortalamasının ( $\mathrm{x}: 24.20)$ kontrol grubunun ön test yaşam doyumu ortalamasına ( $\mathrm{x}: 17.73)$ göre anlamlı düzeyde yüksektir ( $\mathrm{t}=2.806, \mathrm{p}<.05)$. Deney grubunun son test yaşam doyumu düzeyi ortalamasının $(\overline{\mathrm{x}}: 27.33)$ kontrol grubunun son test ortalamasına ( $\mathrm{x}: 17.47)$ göre anlamlı ölçüde yüksek olduğu belirlenmiştir ( $\mathrm{t}=4.930, \mathrm{p}<.01)$. 


\section{TARTIŞMA}

\subsection{Kaygı Düzeyleri Üzerindeki Etkinin Tartışılması}

Araştırmada deney grubunda bulunan katılımcıların ön test ve son test kaygı düzeyleri puan ortalamaları analiz edildiğinde, son test kaygı düzeyi puan ortalamasının ön test kaygı düzeyi puan ortalamasına göre istatistiksel olarak anlamlı düzeyde azaldığı görülmüştür. Buna karşılık kontrol grubunun ön test ve son test kaygı düzeyi puan ortalamalarında istatistiksel olarak anlamlı bir fark görülmemiştir. İki grubun son-test puanlarının karşılaştırılmasına ilişkin bulgular ise istatistiksel açıdan anlamlı bir fark olmadığını işaret etmektedir. Ortaya çıkan bu sonuçlara göre, grup-içi kıyaslamada pilates egzersizlerine katılan bireylerin kaygı düzeylerindeki azalmanın anlamlı olduğu düşünülebilir. Gruplararası kıyaslamada ise, istatistiksel açıdan anlamlı bir sonuç elde edileyemeyişi iki grubun son test puanlarının birbirine oldukça yakın olmasından kaynaklı olabilir. Araştırmada elde edilen bulgu alanyazındaki çalışmalarla da paralellik göstermektedir (Vancini ve ark., 2017; Yucel \& Uysal, 2016, Akbaş \& Ünver, 2018).

İnsanların pilates-mat egzersizine katılımlarıyla yaşamlarında meydana gelen olumlu değişimler kaygı düzeylerinde azalmaya neden olmuş olabilir. Bununla birlikte bireylerin kaygı düzeylerindeki azalma pilates-mat egzersizlerine katılımla hayatlarındaki değişime doğrudan veya dolaylı olarak etki etmiş olabilir. Memmedova (2015) tarafindan bu konuda yapılan bir araştırmada bireylerin pilates-mat egzersizlerine katılımlarıyla uyku kalitelerinin arttığı, yaşam enerjilerinin yükseldiği, egzersiz sayesinde kan dolaşımının hızlanması ve beyne daha fazla oksijen gitmesi sağlanarak stresin azaldığı, pilates-mat egzersizleriyle kasların gevşetildiği dolayısıyla kaygı düzeylerinin pilates-mat egzersizlerine katılımla azaldığg ifade edilmiştir.

\subsection{Depresyon Düzeyleri Üzerindeki Etkinin Tartışılması}

Araştırmada deney grubunda bulunan katılımcıların ön test ve son test depresyon düzeyleri puan ortalamaları analiz edildiğinde, son test depresyon düzeyi puan ortalamasının ön test depresyon düzeyi puan ortalamasına göre istatistiksel olarak anlamlı düzeyde azaldığı görülmüştür. Buna karşılık, pilates egzersizi yapmayan kontrol grubunun ön test ve son test depresyon düzeyi puan ortalamalarında istatistiksel olarak anlamlı bir fark bulunamamıştır. İki grubun karşılaştııılmasında ise deney ve kontrol gruplarının depresyon düzeylerinde son test puanlarında istatistiksel olarak anlamlı bir fark olmadığı görülmüştür. Bu sonuçlara göre pilates-mat egzersizlerine katılımın depresyon düzeyinin azalmasında faydalı olabileceği söylenebilir. Alanyazında yapılan bu konudaki araştırmalar mevcut araştırmanın bulgularıyla paralellik göstermektedir. Pilates-mat egzersizlerinin depresyon üzerine etkisini araştıran birçok çalışma farklı gruplar üzerinde yapılmış ve pilates-mat egzersizlerine katılımın depresyon düzeyini azalttığı rapor edilmiştir (Vancini ve ark., 2017; Hassan \& Amin, 2011; Kamali \& Norouzi, 2016; Öztürk, 2019; Mokhtari ve ark., 2013; Eyigor ve ark., 2010; Halis ve ark., 2016). Bunun yanında yapılan araştırmalarda pilates-mat egzersizlerine katılımın bedensel sağlığı koruyarak depresyon düzeylerini azalttığı da ulaşılan bulgulardandır (Emektar, 2018). Pilates-mat egzersizlerine katılımın bedensel sağlığın yanında ruhsal sağlığı da güçlendirdiği ve dolayısıyla depresyon düzeyinin azalmasına katkıda bulunduğu belirtilmiştir (Suata, 2018).

Alanyazında egzersizler depresyonu azaltan önemli bir unsur olarak görülmüş ve depresyon tedavisinde kullanılabileceğinden bahsedilmiştir (Krogh ark., 2014; Perraton ve ark., 2010; Rosenbaum ve ark., 2014). Depresyonun tedavisinde ilaç kullanımının yanına eklenen egzersizler tedaviye verilen olumlu yanıtı daha da 
artırmaktadır (Trivedi ve ark., 2011). Bireylerin fiziksel sağlığını koruyabilmek, iyileştirebilmek ve geliştirebilmek için pilates egzersizleri yaptığı düşünüldügünde, fiziksel sağlık durumunun iyi olmasının yaşanabilecek depresif belirtileri azaltabileceği düşünülebilir. Egzersizler canlı dokunun eklemlere ve doku hasarına verilen yanıt sürecini etkilediği ve koruyucu etkiye sahip olduğu belirtilmektedir. Yapılan pilates egzersiziyle birlikte koruyucu etkinin devreye girebileceği ifade edilmiştir (McIntyre ve ark., 2009).

\subsection{Yaşam Doyumu Düzeyleri Üzerindeki Etkinin Tartışılması}

Araştırmada deney grubunun ön test ve son test yaşam doyum düzeylerine ait puan ortalamaları karşılaştırıldığında pilates-mat egzersizine katılan deney grubunun son test yaşam doyum düzeyi puan ortalamasının ön test yaşam doyum düzeyi puan ortalamasına göre daha yüksek olduğu görülmüştür. Ön test ve son test ortalamaları arasındaki artış istatistiksel olarak anlamlı bulunmuştur. Buna karşılık, pilates egzersizine katılmayan kontrol grubunun yaşam doyum düzeylerindeki ön test puan ortalaması ile son test puan ortalaması arasında anlamlı bir fark bulunamamıştır. İki grubun karşılaştırılmasına ilişkin bulgularda ise iki grup arasında anlamlı farklılık olduğu ortaya çıkmıştır. Araştırmanın sonucuna göre deney grubundaki katılımcıların yaşam doyum düzeylerinin pilates egzersizlerine katılımla daha da arttığı görülmüştür. Alanyazın araştırmalarında pilates egzersizine katılımın yaşam doyumu üzerine etkisinin araştırıldığı birçok farklı çalışmada da araştırmamızla benzer bulgulara ulaşılmıştır (Naqadeg, 2017; Sharma ve ark., 2018; Curi ve ark., 2018).

Fiziksel açıdan aktif bir yaşamın depresyon ve kaygı gibi olumsuz duyguların daha az yaşanmasına yardımcı olurken, yaşam doyumu gibi olumlu duyguların artmasına etki edebileceği söylenebilir.

\section{SONUC}

Alanyazın incelendiğinde pilates-mat egzersizlerinin ruhsal sağlık üzerine etkisinin araştırıldığı çalışmaların daha az sayıda olduğu görülmüştür. Bununla birlikte Türkiye'de de pilates-mat egzersizlerinin psikolojik sağlık üzerinde etkilerini inceleyen bilimsel araştırmaların da sınırlı sayıda olduğu görülmüştür. Bu nedenle pilates-mat egzersizlerinin psikolojik sağlık üzerine etkilerinin incelenmesinin alanyazına katkı sağlayacağına inanılmaktadır.

Araştırmamızda 18-50 yaş arasındaki kadınların pilates-mat egzersizlerine katılımıyla depresyon ve kaygı düzeylerinde bir değişim ve yaşam doyum düzeylerinde anlamlı bir artış olduğu görülmüştür. Bu bakımdan psikolojik sağlığa katkıda bulunabileceği söylenebilir. Araştırmanın sonuçları alanyazında yapılmış bu konudaki diğer araştırmalarla da paralellik göstermektedir.

Son yıllarda bireylerin kayg1 ve depresyona neden olan birçok sorunla karşılaştığı ve bununla birlikte psikolojik sağlıklarının bozulduğu görülmektedir. Psikolojik sağlığı bozulan bireyler, yaşamdan keyif alamamakta ve mutsuz olmaktadırlar. Bu bireylerin yaşama dair hedefleri ve umutları da azalmaktadır. Bu açıdan bireylerin depresyon ve kaygı düzeylerinin azaltılması noktasında pilates-mat egzersizlerine yönlendirilmesi ve düzenli olarak egzersiz alışkanlığg edinebilecekleri konusunda önerilerde bulunulabilir. Bununla birlikte depresyon ve kaygının azaltılmasında pilates-mat egzersizleri etkisine dair daha fazla görgül araştırmalara da ihtiyaç duyulmaktadır. Bu araştırmada etkinin daha belirgin olarak görüldüğü değişken yaşam doyumudur. Araştırmanın bulguları pilates egzersizlerine katılımın yaşam doyumu üzerinden olumlu etkisinin olduğunu işaret etmektedir. Toplumsal hayatta yaşam doyumu yüksek bireylerin olması, 
sağlıklı bir toplum için gereklidir. Yaşam doyumu yüksek bireyler, iş, meslek ve aile hayatlarında mutlu ve huzurlu olurlar. Bu açıdan bakıldığında pilates-mat egzersizine katılımla yaşam doyum düzeyleri yükselen bireyler sağlıklı bir bedensel ve psikolojik yapıya kavuşabilir. Sağlıklı bireylerin çoğunlukta olduğu bir toplumda sağlıklı nesiller yetişebilir. Toplumda kadınların sağlıklı olmaları, sağlıklı bir toplumun yetişmesi için önemlidir. Pilates egzersizleri, fazla ekipman gerektirmeyen maliyeti düşük, her yerde yapılabilen bireysel veya grup olarak kolaylıkla öğrenilip tek başına yapılabilen bir egzersiz türü olarak yaygınlaştırılabilir. Bununla birlikte psikolojik yardım alan bireylere psikoterapiye ek olarak pilates-mat egzersizleri de önerilebilir.

\section{6. ÖNERILER}

Mevcut araştırmada örnekleme dahil edilen katılımcıların klinik düzeyde depresyonda olmadıklarından, gelecek çalışmalarda depresyon tanısı almış kişilerde psikososyal tedavinin bir parçası olarak pilates-mat egzersizleri dahil edilip, takip edilerek egzersizin etkisinin incelenmesinin uygun olacağı düşünülmektedir. Benzer şekilde, katılımcıların hafif-orta düzeyde kaygılarının olduğu, fakat bunun için tedavi almadıklarından, pilates-mat egzersizlerinin kaygı düzeyi üzerindeki etkisinin kaygı bozukluğu tanısı alan grupta incelenmesi önerilebilir.

\section{ARAŞTIRMANIN SINIRLILIKLARI}

Bu araştırma, 18-50 yaş aralığındaki genç ve orta yetişkin yaşta bulunan 30 kadın katılımcıyla 6 hafta haftada 3 gün olmak üzere deney grubuna yaptırılan 60 dakikalık 18 seans pilates-mat egzersizleriyle, katılımcılara uygulanan ölçeklerle elde edilen verilerle, beyanlarla ve İstanbul iliyle sınırlıdır.

Pilates egzersizleri, araştırmacının ve aynı zamanda pilates eğitmeni olan ve stüdyo sahibi olan eğitmenin verdiği egzersizlerle sınırlıdır. Bu araştırmada kontrol grubu, 6 hafta süreyle herhangi bir egzersiz ve pilates egzersizleri yaptırılmamış olmasıyla sınırlıdır.

\section{ETIKK BEYANI}

İnsan katılımcıları içeren çalışmalar İstanbul Arel Üniversitesi Etik Kurulu tarafından incelenmiş ve onaylanmıştır (23.10.2019 Tarihli 09 No'lu karar).

\section{YAZAR KATKILARI}

Araştırmanın uygulanması, veri toplanması, literatür araştırması ve yazım aşamasında GS, araştırmanın tasarım, düzenleme ve yazım aşamasında ZM görev almıştır.

\section{REFERENCES}

Akbaş, E., \& Ünver, B. (2018). A six-week pilates exercise protocol for improving physical and mental health-related parameters. Malaysian Journal of Movement, Health \& Exercise, 7(2). https://doi.org/10.15282/mohe.v7i2.239

Ardıç, F. (2014). Egzersizin sağlık yararları. Türkiye Fiziksel Tip ve Rehabilitasyon Dergisi, 60, 9-14. https://doi.org/10.5152/tftrd.2014.33716

Avşar, Z. (2019). Sedanter kadınlara uygulanan pilates egzersizlerinin bazı antropometrik özellikler ve performans üzerine etkilerinin incelenmesi [Yayımlanmamış yüksek lisans tezi]. Süleyman Demirel Üniversitesi.

Başoğul, C., \& Buldukoğlu, K. (2015). Depresif bozukluklarda psikososyal girişimler. Psikiyatride Güncel Yaklaşımlar, 7(1), 1-15. https://doi.org/10.5455/cap.20140426072955

Bayram, B., \& Kılıç, L. K. (2017). 5E modelinin 6. sınıf dil bilgisi öğretiminde başarıya ve kalıcılığa etkisi. Erzincan Üniversitesi Ĕ̆itim Fakültesi Dergisi, 19(1), 1-20. https://doi.org/10.17556/erziefd.289948 
Beck, A. T., Ward, C. H., Mendelson, M., Mock, J., \& Erbaugh, J. (1961). An inventory for measuring depression. Archives of General Psychiatry, 4(6), 561-571. https://doi.org/10.1001/archpsyc.1961.01710120031004

Beck, A.T., Epstein, N., Brown, G., \& Steer, R. A. (1988). An inventory for measuring clinical anxiety: psychometric properties. Journal of Consulting and Clinical Psychology, 56(6), 893. https://doi.org/10.1037/0022-006X.56.6.893

Çelik, F.H., \& Hocaoğlu, Ç. (2016). 'Major depresif bozukluk’ tanımı, etyolojisi ve epidemiyolojisi: Bir gözden geçirme. Çağdaş Tlp Dergisi, 6(1), 51-66. https://dergipark.org.tr/en/download/article-file/222312

Çivitçi, A. (2012). Üniversite öğrencilerinde genel yaşam doyumu ve psikolojik ihtiyaçlar arasındaki ilişkiler. Çukurova Üniversitesi Sosyal Bilimler Enstitüsü Dergisi, 21(2), 321-336. https://dergipark.org.tr/en/download/article-file/50773

Cruz-Ferreira, A., Fernandes, J., Gomes, D., Bernardo, L. M., Kirkcaldy, B. D., Barbosa, T. M., \& Silva, A. (2011). Effects of pilates-based exercise on life satisfaction, physical self-concept and health status in adult women. Women \& Health, 51(3), $240-255$. https://doi.org/10.1080/03630242.2011.563417

Curi, V. S., Haas, A. N., Alves-Vilaça, J., \& Fernandes, H. M. (2018). Effects of 16-weeks of pilates on functional autonomy and life satisfaction among elderly women. Journal of Bodywork and Movement Therapies, 22(2), 424-429. https://doi.org/10.1016/j.jbmt.2017.06.014

Dağ, A., Korkutata, A., \& Özavcı, R. (2019). Sportif etkinlik işletmelerinde çalışan personelin öznel iyi oluş düzeyleri ile yaşam doyumlarının bazı değişkenler açısından incelenmesi. International Journal of Sport Exercise and Training Sciences-IJSETS, 5(3), 154-162. https://doi.org/10.18826/useeabd.598909

Damdelen, M. (2016). Sağlıklı bireylerde pilatesin denge üzerine etkisi [Yayımlanmamış doktora tezi]. Haliç Üniversitesi.

Diener, E.D., Emmons, R.A., Larsen, R.J., \& Griffin, S. (1985). The satisfaction with life scale. Journal of Personality Assessment, 49 (1), 71-75. https://doi.org/10.1207/s15327752jpa4901_13

Emektar B. (2018). Pilates egzersizlerinin 30 yaş üstü kadınların abdominal bölge kasları üzerine etkileri [Yayımlanmamış yüksek lisans tezi]. Mehmet Akif Ersoy Üniversitesi.

Eyigor, S., Karapolat, H., Yesil, H., Uslu, R., \& Durmaz, B. (2010). Effects of pilates exercises on functional capacity, flexibility, fatigue, depression and quality of life in female breast cancer patients: a randomized controlled study. Eur J Phys Rehabil Med, 46(4), 481-7.

Fleming, K. M., \& Herring, M. P. (2018). The effects of pilates on mental health outcomes: A meta-analysis of controlled trials. Complementary Therapies in Medicine, 37, 80-95. https://doi.org/10.1016/j.ctim.2018.02.003

Gencer, Y., Çınar, D. A., \& Comba, B. (2015). Stresin ratlarda bazı karaciğer enzimleri (AST, ALT, ALP) üzerine etkilerinin araştırılmas1. Atatürk Üniversitesi Veteriner Bilimleri Dergisi, 10(1), 21-26. https://doi.org/10.17094/avbd.27726

Gönülateş, S., Saygın, Ö., \& İrez, G. B. (2010). Düzenli yürüyüş programının 40-55 yaşları arası bayanlarda sağlı ilişkili fiziksel uygunluk unsurları ve kan lipidleri üzerine etkisi. Uluslarası Insan Bilimleri Dergisi, 7(2), 960-970. https://www.jhumansciences.com/ojs/index.php/IJHS/article/download/1440/629

Güçlü, N. (2001). Stres yönetimi. G.Ü. Gazi Eğitim Bilimleri Fakültesi Dergisi, 21(1), 91-109. http://www.gefad.gazi.edu.tr/en/download/article-file/77499

Halis, F., Yildirim, P., Kocaaslan, R., Cecen, K., \& Gokce, A. (2016). Pilates for better sex: changes in sexual functioning in healthy Turkish women after Pilates exercise. Journal of Sex \& Marital Therapy, 42(4), 302-308. https://doi.org/10.1080/0092623X.2015.1033576

Hassan, E.A.H., \& Amin, M. A. (2011). Pilates exercises influence on the serotonin hormone, some physical variables and the depression degree in battered women. World Journal of Sport Sciences, 5(2), 89-100. https://www.pilatesfisios.it/ricerche\%20pdf/Pilates\%20Exercises\%20Influence\%20on\%20the\%20Serotonin\%20Hormone,.pdf

Hisli, N. (1989). Beck depresyon envanterinin üniversite öğrencileri için geçerliliği, güvenilirliği. J. Psychol., 7, 3-13. https://ci.nii.ac.jp/naid/10028183802/

Kaba, İ., Erol, M., \& Güç, K. (2018). Yetişkin yaşam doyumu ölçeğinin geliştirilmesi. Anadolu Üniversitesi Sosyal Bilimler Dergisi, 18(1), 114. https://doi.org/10.18037/ausbd.550232

Kalfa, S. (2017). Spor bilimleri ve eğitim fakültesi öğrencilerinin yaşam doyumu ve serbest zaman doyumunun incelenmesi (Uşak Üniversitesi örneği) [Yayımlanmamış yüksek lisans tezi]. Sıtk1 Koçman Üniversitesi.

Kamali, A., \& Norouzi, K. (2016). The effect of selected pilates exercises on thigh muscle strength and depression in elderly women. Journal of Paramedical Sciences \& Rehabilitation, 5(2), 67-75. http://eprints.mums.ac.ir/6175/ 
Karataylı, S. (2007). Gebelerde trimesterler arası depresyon, anksiyete, diğer ruhsal belirtiler ve yaşam kalitesi düzeyleri [Yayımlanmamış uzmanlık tezi]. Selçuk Üniversitesi.

K1lı̧, S. (2014). Etki büyüklüğü. Journal of Mood Disorders. 4(1), 44-46. https://doi.org/10.5455/jmood.20140228012836

Kılınç, S., \& Torun, F. (2011). Türkiye'de klinikte kullanılan depresyon değerlendirme ölçekleri. Dirim Tip Gazetesi, 86(1), 39-47. https://dirim.com/Dirim_2011-

1_files/Tu\%CC\%88rkiye\%E2\%80\%99de\%20Klinikte\%20Kullan\%C4\%B1lan\%20Depresyon\%20Deg\%CC\%86erlendirme\%20O\%CC\%8 $8 \mathrm{lc} \% \mathrm{CC} \%$ A7ekleri.pdf

Köker, S. (1991). Normal ve sorunlu ergenlerin yaşam doyumu düzeyinin karşılaştırılması [Yayımlanmamış yüksek lisans tezi]. Ankara Üniversitesi.

Krogh, J., Speyer, H., Nørgaard, H.C.B., Moltke, A., \& Nordentoft, M. (2014). Can exercise increase fitness and reduce weight in patients with schizophrenia and depression?. Frontiers in Psychiatry, 5, 89. https://doi.org/10.3389/fpsyt.2014.00089

Kuran, A. (2018). Üniversite öğrencilerinde yeme tutumu, anksiyete, vücut algısı ve benlik saygısı ilişsisi [Yayımlanmamış yüksek lisans tezi]. Yakın Doğu Üniversitesi.

McIntyre, R.S., Rasgon, N.L., Kemp, D.E., Nguyen, H.T., Law, C.W., Taylor, V.H., ... \& Goldstein, B. I. (2009). Metabolic syndrome and major depressive disorder: Co-occurrence and pathophysiologic overlap. Current Diabetes Reports, 9(1), 51-59. https://doi.org/10.1007/s11892-009-0010-0

Memmedova, K. (2015). Impact of pilates on anxiety attention, motivation, cognitive function and achievement of students: Structural modeling. Procedia-Social and Behavioral Sciences, 186, 544-548. https://doi.org/10.1016/j.sbspro.2015.04.009

Mokhtari, M., Nezakatalhossaini, M., \& Esfarjani, F. (2013). The effect of 12-week pilates exercises on depression and balance associated with falling in the elderly. Procedia-Social and Behavioral Sciences, 70, 1714-1723. https://doi.org/10.1016/j.sbspro.2013.01.246

Naqadeg, H.N. (2017). The effect of pilates exercises on anxiety and quality of sleep in patients with chronic heart failure. Journal of Sport and Exercise Psychology. 3(1), 8-12.

Özdemir, Ö.Ç., \& Uysal, M.F. (2018). Postmenopozal dönemde pilates egzersizlerinin yaşam kalitesi ve depresyon üzerine etkisi. Acıbadem Üniversitesi Să̆lık Bilimleri Dergisi, (1), 25-32. https://dergipark.org.tr/en/download/article-file/1701629

Özdemir, R , İrez, G . (2010). 12 haftalık pilates uygulamalarının 65 yaş üstü kadınlarda algılanan öznel sağlığa etkisi. Spor Bilimleri Dergisi, 21(2), 37-48. https://dergipark.org.tr/en/download/article-file/151270

Öztürk, F. (2019). Pilates method as a kind of mind body practice women practitioners' opinions on their physical and psychological wellbeing [Unpublished doctoral dissertation]. Middle East Technical University.

Perraton, L. G., Kumar, S., \& Machotka, Z. (2010). Exercise parameters in the treatment of clinical depression: a systematic review of randomized controlled trials. Journal of Evaluation in Clinical Practice, 16(3), 597-604. https://doi.org/10.1111/j.1365-2753.2009.01188.x

Rosenbaum, S., Tiedemann, A., Sherrington, C., Curtis, J., \& Ward, P. B. (2014). Physical activity interventions for people with mental illness: A systematic review and meta-analysis. The Journal of Clinical Psychiatry, 75(9). https://www.psychiatrist.com/jcp/eating/physicalactivity-interventions-mental-illness-systematic/

Roshanaei-Moghaddam, B., Katon, W. J., \& Russo, J. (2009). The longitudinal effects of depression on physical activity. General Hospital Psychiatry, 31(4), 306-315. https://doi.org/10.1016/j.genhosppsych.2009.04.002

Sharma, D., Kaur, J., Rani, M., Bansal, A., Malik, M., \& Kulandaivelan, S. (2018). Efficacy of Pilates based mat exercise on quality of life, quality of sleep and satisfaction with life in type 2 diabetes mellitus. Romanian Journal of Diabetes Nutrition and Metabolic Diseases, 25(2), 149-156. http://www.rjdnmd.org/index.php/RJDNMD/article/view/450

Sposito, V. A., Hand, M. L., \& Skarpness, B. (1983). On the efficiency of using the sample kurtosis in selecting optimal $1_{\mathrm{p}}$ estimators. Communications in Statistics-simulation and Computation, 12(3), 265-272. https://doi.org/10.1080/03610918308812318

Suata, C.Ö. (2018). 8 haftalık pilates egzersizlerinin kadın konukevinde kalan şiddet măgduru kadınların psikolojik dayanıklılık, bilişsel çarpıtma ve stresle başa çıkma tarzları üzerine etkisi [Yayımlanmamış yüksek lisans tezi]. Kocaeli Üniversitesi.

Trivedi, M. H., Greer, T. L., Church, T. S., Carmody, T. J., Grannemann, B. D., Galper, D. I., ... \& Henley, S. S. (2011). Exercise as an augmentation treatment for nonremitted major depressive disorder: a randomized, parallel dose comparison. The Journal of Clinical Psychiatry, 72(5), 677-684. https://doi.org/10.1016/10.4088/JCP.10m06743 
Ulusoy, M., Sahin, N.H., \& Erkmen, H. (1998). Turkish version of the Beck Anxiety Inventory: Psychometric properties. Journal of Cognitive Psychotherapy, 12(2), 163.

Vancini, R.L., Rayes, A. B. R., Lira, C.A.B.D., Sarro, K.J., \& Andrade, M. S. (2017). Pilates and aerobic training improve levels of depression, anxiety and quality of life in overweight and obese individuals. Arquivos de Neuro-Psiquiatria, 75, 850-857. https://doi.org/10.1590/0004282X20170149

Yeltepe, H. (2012). Egzersiz psikolojisi ve zihinsel sağglk. Nobel Akademik Yayıncılık.

Yucel, H., \& Uysal, O. (2016). Pilates-based mat exercises and parameters of quality of life in women with type 2 diabetes. Iran Red Crescent Med J, 18(3), 1-6. https://doi.org/10.5812/ircmj.21919 